\title{
The stoichiometry of coral-dinoflagellate symbiosis: carbon and nitrogen cycles are balanced in the recycling and double translocation system
}

\author{
Yasuaki Tanaka $^{1,2} \cdot$ Atsushi Suzuki $^{3} \cdot$ Kazuhiko Sakai $^{1}$ \\ Received: 22 June 2017 / Revised: 30 October 2017 / Accepted: 2 November 2017 / Published online: 12 January 2018 \\ (c) International Society of Microbial Ecology 2018
}

\begin{abstract}
Symbioses between microalgae and animal hosts have the advantage of acquiring and sharing autotrophically produced organic carbon (C) as their energy source. However, the stoichiometry and turnover rates of biological elements in symbioses are not fully understood because of complicated metabolic interactions. We report the first comprehensive and simultaneous measurement of $\mathrm{C}$ and nitrogen $(\mathrm{N})$ flows through coral-dinoflagellate symbiosis by using the unique approach of dual-isotope labeling with ${ }^{13} \mathrm{C}$ and ${ }^{15} \mathrm{~N}$, in situ chasing, and isotope-mixing models. The coral autotrophy occurred with much lower $\mathrm{C}: \mathrm{N}$ ratios than previously thought, and the autotrophically produced $\mathrm{N}$-rich organic matter was efficiently transferred to the animal host through two different pathways. In contrast to the dynamic $\mathrm{N}$ cycles within the symbiosis, the $\mathrm{N}$ uptake from the ambient seawater was extremely limited, which enabled the coral symbiosis to sustain $\mathrm{N}$ with a long turnover time (1 year). These findings suggest that coral endosymbionts are not under $\mathrm{N}$ limitation but are actively producing organic $\mathrm{N}$ and driving microscale $\mathrm{N}$ cycles in the reef ecosystem. The present techniques could be applied to further quantify the $\mathrm{C}$ and $\mathrm{N}$ cycles in other symbiotic interactions and reveal their ecological advantages.
\end{abstract}

\section{Introduction}

Symbioses between microbes and plant or animal hosts are commonly seen on our planet (e.g., lichens and mycorrhizae). In aquatic ecosystems, diverse invertebrates (e.g., corals, sea anemones, tridacnid clams, foraminiferans, jellyfish, sponges, radiolarians, hydrozoans, and ascidians) are symbiotic with microalgae (e.g., the genera Symbiodinium, Chlorella, and Prochloron) and many of them are found in shallow tropical seawaters $[1,2]$. These symbiotic

Electronic supplementary material The online version of this article (https://doi.org/10.1038/s41396-017-0019-3) contains supplementary material, which is available to authorized users.

Yasuaki Tanaka

yasuaki.tanaka@ubd.edu.bn

1 Sesoko Station, Tropical Biosphere Research Center, University of the Ryukyus, 3422 Sesoko, Motobu, Okinawa 905-0227, Japan

2 Faculty of Science, Universiti Brunei Darussalam, Jalan Tungku Link, Gadong BE1410, Brunei Darussalam

3 Geological Survey of Japan, National Institute of Advanced Industrial Science and Technology (AIST), 1-1-1 Higashi, Tsukuba 305-8567, Japan associations would be advantageous because the animal host can easily acquire energy in the form of autotrophically produced organic carbon (C) from the algal symbionts [36]. This characteristic feature of autotroph-heterotroph symbioses (i.e., the acquisition and allocation of photosynthetically fixed organic C) has been the main target of research for understanding the symbiotic metabolism, which led to the development of C-based theories and models $[4,7,8]$.

Scleractinian corals are the most representative and fundamental organisms in coral reefs and have been a model of studies on autotroph-heterotroph symbioses $[1,2]$. They have symbiotic dinoflagellates (Symbiodinium) in the host endodermis, and the endosymbiotic algae actively produce photosynthates, which are then translocated to the animal host, despite the limited availability of nutrients in the ambient seawater [5, 7, 8]. In recent decades, coral ecophysiology has been well studied to assess the effects of global and local environmental changes on coral reef ecosystems $[9,10]$. With the concerns about coastal eutrophication, the effects of inorganic nitrogen (N) and phosphorus (P) on coral symbioses have also been evaluated using both laboratory experiments and field observations [11-13]. Consequently, the cycles of 
major biological elements (e.g., C, N, and P) in autotroph-heterotroph symbioses have been studied and described more for the scleractinian corals than for other symbiotic organisms [7, 8, 14-16]. However, most previous studies discussed each biological element separately; thus, the stoichiometric perspectives are still missing, and we do not have a general concept of the quality (e.g., C:N:P ratio) and turnover rate of metabolism in coral symbiosis.

Coral reefs maintain highest gross primary production rates per unit surface area among marine ecosystems, despite being filled with oligotrophic seawater [17]. This paradoxical ecosystem structure has been explained by the active production of organic matter with imbalanced, high $\mathrm{C}: \mathrm{N}$ or $\mathrm{C}: \mathrm{P}$ ratios [17]. However, the specific $\mathrm{C}: \mathrm{N}: \mathrm{P}$ stoichiometry in coral reefs has scarcely been studied because the oligotrophic reef water makes it difficult to detect the tiny $\mathrm{N}$ and $\mathrm{P}$ fluxes through organisms [18-21], and many symbiotic reef organisms (see above) have complicated metabolic pathways [3, 6, 15, 16, 22]. Coral reefs are rapidly declining due to global and local environmental stresses [10, 23, 24], and a better understanding of the cycles of biological elements at the ecosystem scale as well as at the organism scale is urgently needed [25-27].

Dual-isotope labeling with ${ }^{13} \mathrm{C}$ and ${ }^{15} \mathrm{~N}$ and the subsequent chasing of these tracers by measuring the ${ }^{13} \mathrm{C}$ and ${ }^{15} \mathrm{~N}$ isotope ratios $\left(\delta^{13} \mathrm{C}\right.$ and $\delta^{15} \mathrm{~N}$, respectively) provide a powerful technique for simultaneously assessing $\mathrm{C}$ and $\mathrm{N}$ cycles, and this method has been used in ecological and biological studies [27-29]. Several studies have applied this pulse-chase technique to corals to study basic physiology or response to thermal stress [5, 30-32]. However, those studies were conducted only under laboratory conditions, and the short experimental periods ( $<2$ weeks) failed to quantify the relatively long turnover of $\mathrm{N}$ in the coral symbiosis. Quantifying N turnover in autotroph-heterotroph symbioses is important for understanding the survival and adaptive strategies of the organisms under N-limited environments, such as the organisms in coral reefs. In stable isotope ecology and geochemistry, $\delta^{15} \mathrm{~N}$ is used for estimating $\mathrm{N}$ sources for an organism [33-35], where $\mathrm{N}$ turnover affects the rate of change in $\delta^{15} \mathrm{~N}$ in the organism and can produce a time lag with respect to the changes in the $\mathrm{N}$ sources.

To better understand coral symbiotic associations as well as biogeochemical cycles in coral reefs, it is necessary to quantify the stoichiometry and turnover of $\mathrm{C}$ and $\mathrm{N}$ in coral symbiosis. In the present study, we first labeled the coral Porites cylindrica, which is one of the major coral species at our study site, with ${ }^{13} \mathrm{C}$-labeled bicarbonate and ${ }^{15} \mathrm{~N}$-labeled nitrate in an outdoor tank (Table S1). Then, we placed the corals back into the reef and chased the isotope tracers in the corals for 1 month, allowing us to evaluate the coral $\mathrm{C}$ and $\mathrm{N}$ metabolism under in situ conditions. The coral fragments were collected from the field as scheduled, and the $\delta^{13} \mathrm{C}$ and $\delta^{15} \mathrm{~N}$ and the organic $\mathrm{C}$ and $\mathrm{N}$ contents of both the endosymbionts and the animal host tissues were measured. Moreover, other key aspects of $\mathrm{C}$ and $\mathrm{N}$ metabolism related to the endosymbionts (e.g., algal density and proliferation rate) and the animal host (e.g., the release rate of organic matter to the ambient seawater) were determined from additional experiments. Using the obtained data, the comprehensive $\mathrm{C}$ and $\mathrm{N}$ stoichiometry and the turnover rates in the coral symbiosis were calculated from the isotope-mixing models.

\section{Materials and methods}

\section{Coral preparation}

Fragments of Porites cylindrica (2-3 cm long, $1-1.5 \mathrm{~cm}$ wide) were collected from four colonies at a depth of 2-2.5 m near Sesoko Island, Okinawa, Japan $\left(26^{\circ} 37-39^{\prime} \mathrm{N}\right.$, $127^{\circ} 51-52^{\prime}$ E) in September 2014, and the fragments were transferred to the Sesoko Research Station (University of the Ryukyus). After the coral fragments were attached to plastic bolts ( $n=15$ per colony, total $n=60$ ), they were placed in an outdoor flow-through tank at the research station and allowed to recover from the fragmentation. The seawater was freshly pumped from the coral reef in front of the research station and supplied to the tank without filtration. The tank was shaded with screens to simulate insolation levels at a depth of $2 \mathrm{~m}$ for all of the subsequent experiments. After 3 weeks of recovery, the coral fragments growing on the bolts were fixed onto plastic plates by using nuts, and the plates with the corals were fixed onto a concrete block and were then moved back to the natural reef environment near the original site of coral collection. The corals were acclimated to the reef environment for 1 week before the following labeling experiment was conducted.

\section{Pulse-chase experiment with ${ }^{13} \mathrm{C}$ and ${ }^{15} \mathrm{~N}$}

After the coral fragments were transferred from the reef to the research station, four coral fragments (one fragment per colony) were collected to measure the original $\delta^{13} \mathrm{C}$ and $\delta^{15} \mathrm{~N}$ values (Table S1). Twenty fragments $(n=5$ per colony) were placed in a closed tank with $8.0 \mathrm{~L}$ of natural 0.5 $\mu \mathrm{m}$-filtered seawater (FSW). The concentrations of nitrate $\left(\mathrm{NO}_{3}{ }^{-}\right)$, nitrite $\left(\mathrm{NO}_{2}{ }^{-}\right)$, ammonium $\left(\mathrm{NH}_{4}{ }^{+}\right)$, and phosphate $\left(\mathrm{PO}_{4}{ }^{3-}\right)$ in the FSW were measured using a nutrient analyzer (AACS-II, Bran+Luebbe, Germany) and were 0.73, $0.24,0.30$, and $0.08 \mu \mathrm{mol} \mathrm{L}^{-1}$, respectively. Stock solutions of $\mathrm{NaH}^{13} \mathrm{CO}_{3}$ and $\mathrm{K}^{15} \mathrm{NO}_{3}$ were added to the seawater to increase their concentrations by $0.2 \mathrm{mmol} \mathrm{L}^{-1}$ and $5.0 \mu \mathrm{mol}$ $\mathrm{L}^{-1}$, respectively. The seawater in the tank was circulated by bubbling air, and the corals received adjusted sunlight. The process of labeling the corals with ${ }^{13} \mathrm{C}$ and ${ }^{15} \mathrm{~N}$ started 
at noon and continued for $24 \mathrm{~h}$ (i.e., the pulse period). The remaining 36 fragments ( $n=9$ per colony) were placed in an outdoor flow-through tank at the research station, and the buoyant weight of each fragment was measured to allow for the later calculations of their calcification rates.

After the pulse period, four coral fragments (one fragment per colony) were collected from the ${ }^{13} \mathrm{C}$ - and ${ }^{15} \mathrm{~N}$ enriched tank to analyze the initial $\delta^{13} \mathrm{C}$ and $\delta^{15} \mathrm{~N}$ values (day 0) (Table S1). All other coral fragments, including the ones that were not labeled, were transferred back to the natural reef environment to chase ${ }^{13} \mathrm{C}$ and ${ }^{15} \mathrm{~N}$ in the labeled coral fragments under in situ conditions (i.e., the chase period), where the corals were acclimated before labeling. On days 2, 10,20, and 30, four fragments (one fragment per colony) were collected from the labeled corals for $\delta^{13} \mathrm{C}$ and $\delta^{15} \mathrm{~N}$ analyses. On day 21 , the 36 unlabeled fragments were transferred to the research station, and the buoyant weight of each fragment was measured to calculate the calcification rates. Then, the unlabeled coral fragments were used to measure the mitotic index of the endosymbionts, the release rates of the endosymbionts, and the release rates of total organic N (TON) from the coral fragments. Detailed descriptions of the experiments that used the unlabeled corals are provided in the Supplementary Information, Sections 1 and 2. $\mathrm{NO}_{3}{ }^{-}, \mathrm{NO}_{2}{ }^{-}, \mathrm{NH}_{4}{ }^{+}$, and $\mathrm{PO}_{4}{ }^{3-}$ concentrations at the reef site were measured every few days during the chase period and were $0.40 \pm 0.15,0.10 \pm 0.01$, $0.82 \pm 0.49$, and $0.04 \pm 0.01 \mu \mathrm{mol} \mathrm{L}{ }^{-1}$ (mean \pm 1 s.d., $n=$ 7 ), respectively. The seawater temperature and daytime light intensity (0900-1500 h) at the depth of the corals were monitored every 30 min using a data logger (HOBO, Onset, Bourne, MA, USA), and the average values were $25.4{ }^{\circ} \mathrm{C}$ and 13,300 lux, respectively.

The coral fragments collected before labeling and on days $0-30$ for the $\delta^{13} \mathrm{C}$ and $\delta^{15} \mathrm{~N}$ analyses were processed with the Water Pik technique to remove coral animal tissue and endosymbionts from a longitudinal half of the coral fragment. The tissue suspension was centrifuged at $450 \times g$ for $5 \mathrm{~min}$ to separate the endosymbionts (pellet) from the animal host (supernatant). The endosymbiont pellet was suspended with FSW, and the suspension was centrifuged again to purify the endosymbiont fraction. The second algal pellet was suspended with $2 \mathrm{~mL}$ of distilled water and stored in a freezer until analysis. The remaining half of the coral fragment, which still contained coral tissue, was immersed in $5 \mathrm{~mL}$ of $\mathrm{NaOH}$ solution $(1 \mathrm{~N})$ at $70^{\circ} \mathrm{C}$ for $2 \mathrm{~h}$, and the whole coral tissue (animal host tissue + endosymbionts) was dissolved. This subsample was also stored in a freezer until analysis.

\section{Laboratory analyses and calculations}

The $\delta^{13} \mathrm{C}$ and $\delta^{15} \mathrm{~N}$ in the endosymbionts and whole coral tissue were measured with an ANCA-GSL elemental analyzer interfaced with a 20-22 isotope ratio mass spectrometer (Sercon Ltd., Cheshire, UK). The abundance of ${ }^{13} \mathrm{C}$ and ${ }^{15} \mathrm{~N}$ was expressed as the per mil deviation of ${ }^{13} \mathrm{C} /$ ${ }^{12} \mathrm{C}\left(\delta^{13} \mathrm{C}\right)$ relative to Vienna Pee Dee belemnite (v-PDB) and as the per mil deviation of ${ }^{15} \mathrm{~N} /{ }^{14} \mathrm{~N}\left(\delta^{15} \mathrm{~N}\right)$ relative to air, respectively. The contents of the organic $\mathrm{C}$ and $\mathrm{N}$ in the endosymbionts and the whole coral tissue were normalized to the unit skeletal surface area $\left(\mathrm{cm}^{2}\right)$, which was determined by using the aluminum foil method [36]. The contents and isotope ratios of organic $\mathrm{C}$ and $\mathrm{N}$ in the animal host tissue were calculated by subtracting the endosymbiont fraction from the whole tissue. Detailed descriptions of the laboratory analyses and calculations are provided in the Supplementary Information, Section 3.

\section{N metabolic model}

The $\mathrm{N}$ model describes $\mathrm{N}$ flows through the endosymbionts and the animal host (Fig. 1) and has been developed based on previous models $[15,37]$. First, the $\mathrm{N}$ and ${ }^{15} \mathrm{~N}$ mass balances of the endosymbionts and the animal host were described with simultaneous differential equations, and the equations were transformed to express the $\delta^{15} \mathrm{~N}$ of the endosymbionts $\left({ }^{15} N_{\mathrm{e}}\right)$ and animal host $\left({ }^{15} N_{\mathrm{h}}\right)$ as a function of time (days). Then, ${ }^{15} N_{\mathrm{e}}$ and ${ }^{15} N_{\mathrm{h}}$ were simulated with variables so that they were best fit to the observed changes in $\delta^{15} \mathrm{~N}$. The simulation result was evaluated from the sum of the squared differences between the observed and simulated $\delta^{15} \mathrm{~N}$ values of the endosymbionts and animal host from days 2 to 30. Detailed descriptions of the $\mathrm{N}$ model are provided in the Supplementary Information, Section 4.

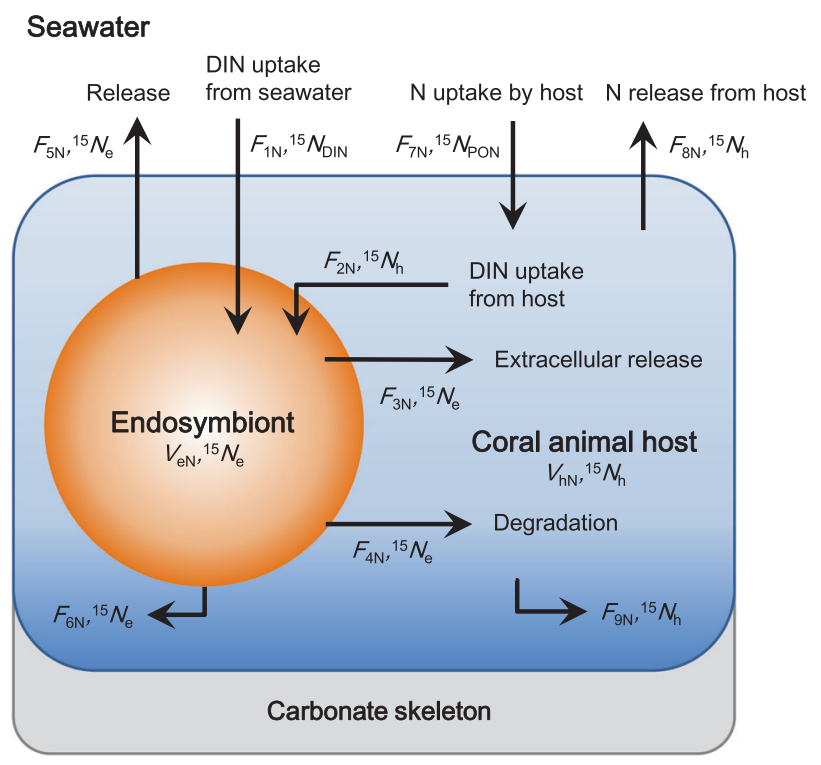

Fig. 1 Nitrogen $(\mathrm{N})$ flows through coral-dinoflagellate symbiosis for the $\mathrm{N}$ model. See Table 1 and Fig. 3 for descriptions of the symbols 


\section{C metabolic model}

The $\mathrm{C}$ model was calculated from the combination of the above $\mathrm{N}$ model and the observed $\delta^{13} \mathrm{C}$ decline of the endosymbionts and the whole coral tissue. Briefly, the algal gross photosynthetic rate was calculated from the exponential decay of $\delta^{13} \mathrm{C}$ in the whole coral tissue. The turnover rates and sizes of two $\mathrm{C}$ pools in the endosymbionts were determined from the exponential decay of $\delta^{13} \mathrm{C}$ in the endosymbionts. The $\mathrm{C}$ pathways involved in the degradation of the endosymbionts, the release of endosymbionts to the ambient seawater, and skeletal growth were calculated from the corresponding $\mathrm{N}$ fluxes and the $\mathrm{C}: \mathrm{N}$ ratio of the endosymbionts. Detailed descriptions of the $\mathrm{C}$ model are provided in the Supplementary Information, Section 5.

\section{Sensitivity analyses}

The parameters measured in the present study may involve some variability that adds uncertainty to subsequent model calculations. Specifically, the release rates of endosymbionts and organic matter from the coral and the mitotic index of the endosymbionts were measured under outdoor laboratory conditions, and the rate of increase in the surface area of the skeleton was estimated from the calcification rate. Each of these values was changed by $\pm 20 \%$, and the $\mathrm{N}$ and $\mathrm{C}$ models were run to assess the sensitivity of some key parameters in the present study. The percent difference between each run and the original model output was calculated.

\section{Statistics}

The time-course changes of the $\mathrm{C}$ and $\mathrm{N}$ contents of the endosymbionts, animal hosts, and whole tissue per unit skeletal surface area were tested by Pearson's correlation test, and none of these variables significantly changed with time $(p>0.05)$. Thus, the mean \pm 1 s.d. of the four coral colonies was determined for the entire chase period. All other data that were directly measured in the experiments are also presented as the mean \pm 1 s.d. for the four coral colonies. The $\delta^{13} \mathrm{C}$ changes in the endosymbionts and the whole tissue were fit to an exponential decay model of one pool or two pools, and the better of the two decay models was selected by considering the coefficient of determination $\left(r^{2}\right)$ and the $p$ values of the coefficients. The $\mathrm{N}$ and $\mathrm{C}$ metabolic models were calculated using the mean values of the variables. All statistical analyses and curve fitting were performed using JMP 11 (SAS Institute, Cary, NC, USA) and SigmaPlot 12.5 (Systat Software, San Jose, CA, USA), respectively.

\section{Results and discussion}

During the chase period, the $\delta^{15} \mathrm{~N}$ of the endosymbionts gradually declined, whereas that of the animal host increased and became similar to that of the endosymbionts after 30 days (Fig. 2a). Because the $\mathrm{N}$ content of each fraction was constant during the chase period (Table 1), the converging trend of $\delta^{15} \mathrm{~N}$ in the endosymbionts and animal host indicates that $\mathrm{N}$ was shared and exchanged between the two fractions. The proliferation rate of the endosymbionts was $3.06 \% \mathrm{~d}^{-1}$, and the endosymbionts were used for the expansion of the coral
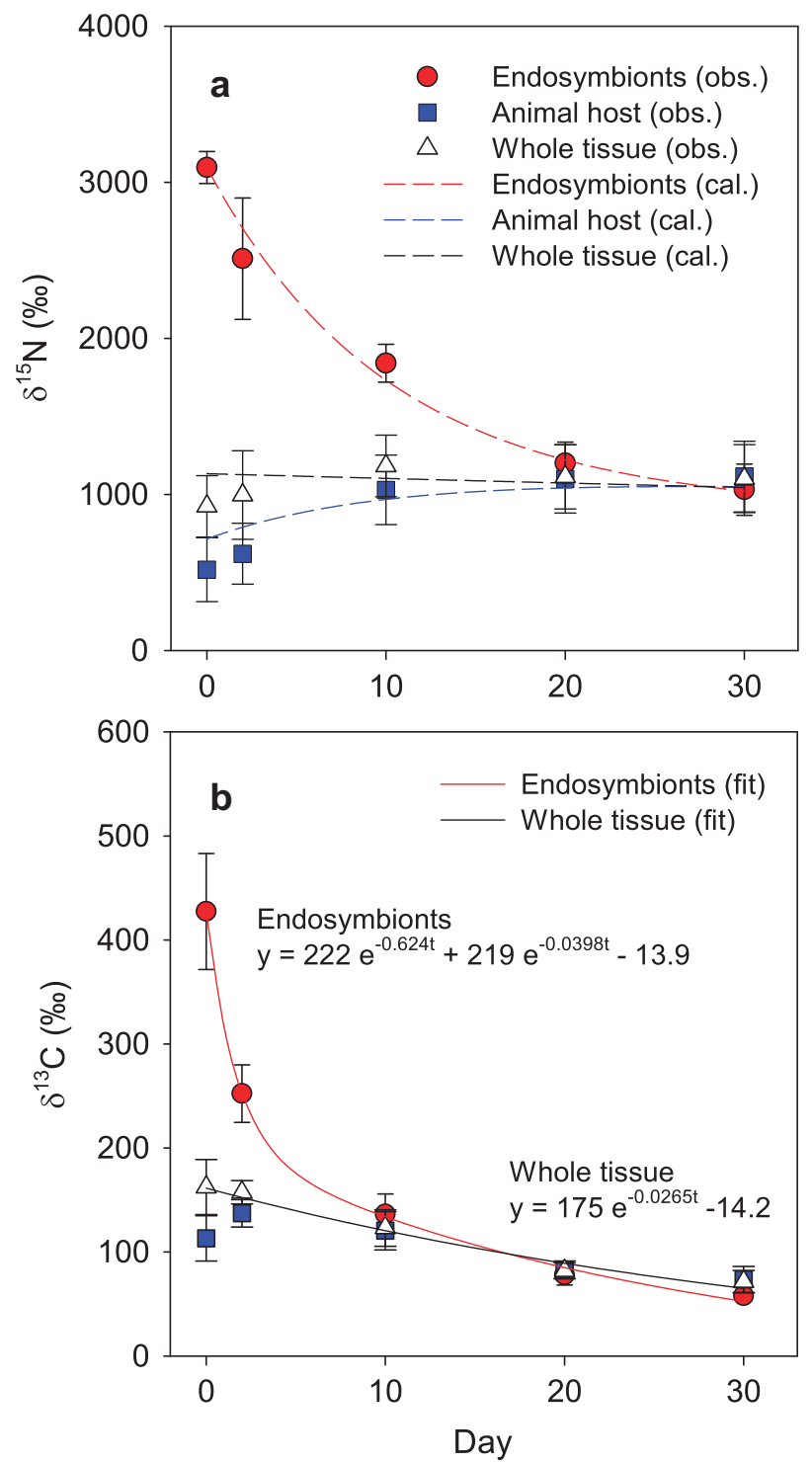

Fig. 2 The $\delta^{15} \mathrm{~N}$ (a) and $\delta^{13} \mathrm{C}$ (b) of the endosymbionts, animal host, and whole tissues of the coral Porites cylindrica during the chase period. Plots, dashed lines, and solid lines indicate observed values (obs.), results calculated from the model (cal.), and curve fitting (fit), respectively. The observed values are shown as the mean \pm 1 s.d. for the four different coral colonies 
Fig. 3 The summary of $\mathrm{C}$ and $\mathrm{N}$ flows through the coral Porites cylindrica. The fluxes and pools are normalized to the unit surface area of the coral (nmol $\mathrm{cm}^{-2} \mathrm{~d}^{-1}$ and $\mathrm{nmol} \mathrm{cm}{ }^{-2}$, respectively). $F_{1}$ : uptake of inorganic $\mathrm{C}$ and $\mathrm{N}$ from seawater; $F_{2}$ : DIN uptake from animal host; $F_{3}$ : extracellular release of organic matter; $F_{4}$ : degradation of endosymbionts; $F_{5}$ : release of endosymbionts to seawater; $F_{6}$ : allocation of endosymbionts to coral skeletal growth; $F_{7}$ : uptake of organic matter by animal host; $F_{8}$ : release of organic matter from animal host to seawater; $F_{9}$ : allocation of animal host tissue to coral skeletal growth; $F_{10}$ : respiration of endosymbionts; $F_{11}$ : respiration of animal host; and $G$ : calcification. *[19], **[60]

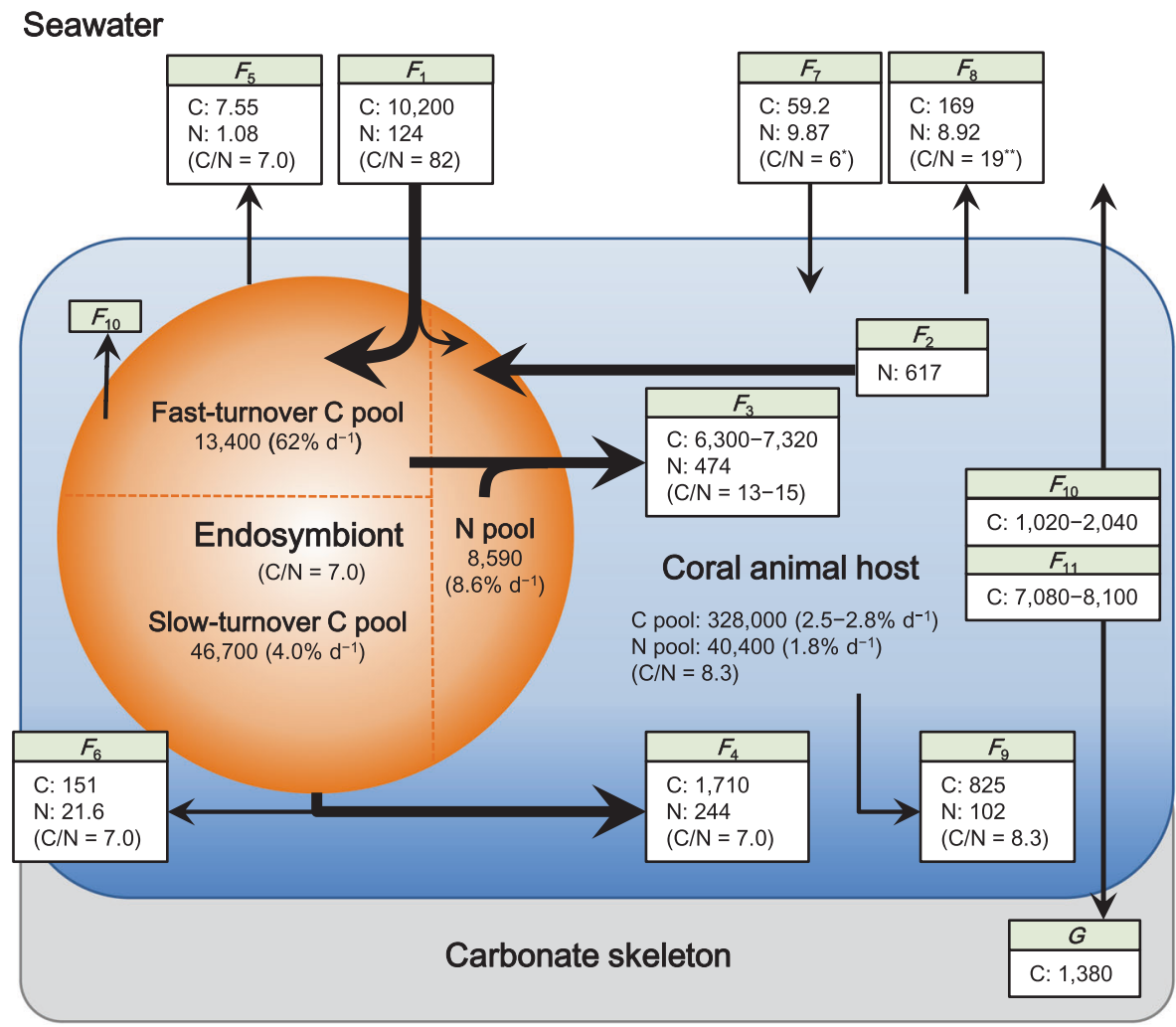

skeletal surface at a rate of $0.252 \% \mathrm{~d}^{-1}$ (Table 1). Because the release rate of the endosymbionts to the ambient seawater was $0.0126 \% \mathrm{~d}^{-1}$, the remaining endosymbionts $\left(2.80 \% \mathrm{~d}^{-1}\right)$ should be degraded in the host tissue (Fig. 1 and Table 1). These rates of proliferation, release, and degradation are comparable to those observed in previous studies [38-40]. Using the $\mathrm{N}$ content and the $\mathrm{C}: \mathrm{N}$ ratio of the endosymbionts, the $\mathrm{C}$ and $\mathrm{N}$ fluxes involved in the algal degradation $\left(F_{4}\right)$, release $\left(F_{5}\right)$, and allocation to the skeletal growth of corals $\left(F_{6}\right)$ were determined, as shown in Fig. 3.

The results of the $\mathrm{N}$ model showed that the endosymbionts obtained 124 and $617 \mathrm{nmol} \mathrm{cm}{ }^{-2} \mathrm{~d}^{-1}$ from the ambient seawater $\left(F_{1}\right)$ and the $\mathrm{N}$ pool in the host tissue $\left(F_{2}\right)$, respectively (Fig. 3). The $F_{2}$ percentage of the total $\mathrm{N}$ acquisition of the endosymbionts $(83 \%)$ was equivalent to previous estimates (73-90\%) for symbiotic dinoflagellates in corals $[14,15]$ and foraminiferans [41], and this indicates that the recycling of host-derived $\mathrm{N}$ by endosymbionts strongly supports the algal primary production. The results of the $\mathrm{N}$ model also showed that a large part $(64 \%)$ of the total $\mathrm{N}$ that was incorporated in the endosymbionts was used for extracellular release to the animal host $\left(F_{3}\right)$. The percentage of the extracellular $\mathrm{N}$ release (PER) of the coral endosymbionts is among the highest levels recorded for marine phytoplankton [42, 43] and may be caused by a so-called "host release factor" (HRF), which induces the release of photosynthates from endosymbionts to the host tissue [44, 45]. HRFs have mainly been studied in corals and sea anemones [46] but are also known for many other alga-invertebrate symbioses, e.g., the giant clam Tridacna crocea [47], the sea slug Elysia viridis [48], and the freshwater ciliate Paramecium bursaria [49]. The remaining $36 \%$ of the $\mathrm{N}$ was used to produce endosymbiont cells, though most of the produced endosymbionts were degraded in the animal host tissue $\left(F_{4}\right)$, as shown above. In addition to extracellular release, the degradation of endosymbionts contributes substantially to the acquisition of $\mathrm{N}$ by the animal host.

In total, $97 \%$ of the $\mathrm{N}$ incorporated into the endosymbionts was translocated to the host tissue via extracellular release or cell degradation. The present $\mathrm{N}$ model suggests that this double translocation system drives the efficient transfer of autotrophically produced organic matter to the animal host and promotes active $\mathrm{N}$ cycles between the symbiotic partners. The allocation of algal photosynthates to the two different pathways (i.e., extracellular release or mitosis) alters the quality and turnover of the organic matter that is provided to the animal host: a portion of the algal photosynthates is quickly released to the host tissue for its daily metabolism, such as respiration $[5,30]$. The remaining portion of the algal photosynthates is invested into the algal mitosis, and the produced algal cells would have a different chemical composition from the released organic matter (e.g., lower $\mathrm{C}: \mathrm{N}$ ratios); this portion is slowly produced and gradually digested by the animal host. From a C-based perspective, it was proposed that phototroph-heterotroph 
Table 1 The summary of symbols and values obtained from the experiments

\begin{tabular}{llll}
\hline Symbol & Description & Value & Unit \\
\hline$V_{\mathrm{eN}}$ & N content of endosymbionts & $8,590 \pm 1,680$ & $\mathrm{nmol} \mathrm{cm}^{-2}$ \\
$V_{\mathrm{eC}}$ & C content of endosymbionts & $60,100 \pm 11,900$ & $\mathrm{nmol} \mathrm{cm}^{-2}$ \\
$V_{\mathrm{hN}}$ & N content of animal host & $40,400 \pm 3,800$ & $\mathrm{nmol} \mathrm{cm}^{-2}$ \\
$V_{\mathrm{hC}}$ & C content of animal host & $328,000 \pm 32,000$ & $\mathrm{nmol} \mathrm{cm}^{-2}$ \\
$N_{\mathrm{t}}$ & Abundance of endosymbionts in the animal host & $9.10 \pm 1.02$ & $10^{5} \mathrm{cells} \mathrm{cm}^{-2}$ \\
$M I$ & Mitotic index of endosymbionts & $3.11 \pm 0.20$ & $\%$ \\
$P$ & Proliferation rate of endosymbionts & $3.06 \pm 0.20$ & $\% \mathrm{~d}^{-1}$ \\
$P R_{\mathrm{e}}$ & Proportion of endosymbionts released from the animal & $0.0126 \pm 0.0034$ & $\% \mathrm{~d}^{-1}$ \\
& host & $10.0 \pm 8.7$ & $\mathrm{nmol} \mathrm{cm}^{-2} \mathrm{~d}^{-1}$ \\
$R_{\mathrm{TON}}$ & Release rate of total organic N & $1.15 \pm 0.08$ & $\mathrm{mg} \mathrm{CaCO}_{3} \mathrm{~cm}^{-2} \mathrm{~d}^{-1}$ \\
$G$ & Calcification rate & 0.252 & $\% \mathrm{~d}^{-1}$ \\
$G_{\mathrm{s}}$ & Expansion rate of coral skeletal surface area & - & $\%$ \\
${ }^{15} N_{\mathrm{e}}$ & $\delta^{15} \mathrm{~N}$ of endosymbionts & - & $\%$ \\
${ }^{15} N_{\mathrm{h}}$ & $\delta^{15} \mathrm{~N}$ of animal host & $3[61]$ & $\% \%$ \\
${ }^{15} N_{\mathrm{DIN}}$ & $\delta^{15} \mathrm{~N}$ of DIN in seawater & $7[62]$ & $\%$ \\
${ }^{15} N_{\mathrm{PON}}$ & $\delta^{15} \mathrm{~N}$ of particulate organic N in seawater & & \\
\hline
\end{tabular}

The values that were directly measured in the experiments are shown as the mean \pm 1 s.d. for the four different colonies symbioses experience a "trade-off" for the use of the produced photosynthates and that the pool of photosynthetically fixed $\mathrm{C}$ is shared between the processes of extracellular release to the host tissue and algal cell production [4]. However, the present N-based model suggests that the allocation of algal photosynthates is not simply a trade-off; rather, there are two different pathways for $\mathrm{C}$ and $\mathrm{N}$ to effectively maintain the metabolic processes of the symbiosis. Therefore, most of the $\mathrm{N}$ that is incorporated into endosymbionts is eventually recovered by the animal host, regardless of which pathway $\mathrm{N}$ is used for.

The $\delta^{13} \mathrm{C}$ of the endosymbionts showed a rapid exponential decline during the chase period, and this change fit the two-pool model well (Fig. 2b). The turnover rates of the two $\mathrm{C}$ pools in the coral endosymbionts were approximately estimated by nanoscale secondary ion mass spectrometry (NanoSIMS) and transmission electron microscopy [30], and the study showed that the algal photosynthates were temporarily stored as lipid droplets and starch granules (i.e., $\mathrm{C}$ reserves) in the fast-turnover pool. The present study quantified the exact turnover rates and estimated the volumes of the two $\mathrm{C}$ pools in the endosymbionts (Fig. 3). The rate of the fast-turnover pool $\left(62 \% \mathrm{~d}^{-1}\right)$ indicated that the $\mathrm{C}$ pool was quickly replaced with new photosynthates that were synthesized with the dissolved inorganic C (DIC) absorbed from the ambient seawater. This aligns with the observation that coral endosymbionts acquire DIC for photosynthesis mainly from the ambient seawater, not from the metabolic $\mathrm{CO}_{2}$ pool in the animal host [50]. The rate of $\mathrm{C}$ efflux from the slow-turnover pool (1860 $\left.\mathrm{nmol} \mathrm{cm}^{-2} \mathrm{~d}^{-1}\right)$, which was calculated from the pool size and its turnover rate (Fig. 3), was close to the $\mathrm{C}$ flux to the animal host as a result of the degradation of the endosymbionts $\left(F_{4}: 1710 \mathrm{nmol} \mathrm{C} \mathrm{cm}^{-2}\right.$ $\left.\mathrm{d}^{-1}\right)$. This correspondence indicated that the slow-turnover pool of endosymbionts was mainly replaced by the degradation of the algal cell.

While the apparent $\mathrm{C}: \mathrm{N}$ ratio of the DIC to the dissolved inorganic $\mathrm{N}$ (DIN) uptake from the ambient seawater in the endosymbionts was 82 , the actual $\mathrm{C}: \mathrm{N}$ ratio of the DIC to DIN uptake ( $\left.\mathrm{C}: \mathrm{N}_{\text {uptake }}\right)$ for the gross photosynthesis, considering internally recycled $\mathrm{N}\left(F_{2}\right)$, was 14 (Fig. 3). This is the first report that quantifies the apparent and actual DIC:DIN uptake ratios of coral endosymbionts under field conditions, and we found that the actual ratio was much lower than the apparent ratio but was similar to the DIC:DIN uptake ratio observed for marine phytoplankton under nutrient-enriched conditions [51, 52]. The $\mathrm{C}: \mathrm{N}$ ratio of the organic matter that was released from the endosymbionts $\left(\mathrm{C}: \mathrm{N}_{\text {release }}\right)$ was estimated to be 13-15 (Fig. 3), which is also much lower than previous estimates (23-30) [5, 53]; this is because the internal $\mathrm{N}$ availability $\left(F_{2}\right)$ was included in the calculations in the present study. Similar low $\mathrm{C}: \mathrm{N}$ ratios (14-17) were reported from the extracellular release from marine diatoms cultured under nutrient-enriched conditions (14-17) [51, 54]. The organic matter released from endosymbionts to the coral animal host has been referred to as "junk food" [7] because of the high $\mathrm{C}: \mathrm{N}$ ratio that is calculated when only the DIN from seawater is considered. However, the present study 
suggests that this organic matter may be a rather nutritious food source. Sensitivity analyses for the $\mathrm{C}$ and $\mathrm{N}$ models

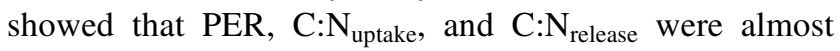
unaffected by the algal mitotic index, the coral skeletal growth rate, and the fluxes between the corals and the ambient seawater (Table S2). Coral endosymbionts have been believed to be under $\mathrm{N}$ limitation because the density of algal cells and/or chlorophyll is elevated in nutrientenriched seawater $[12,55]$. However, the present findings

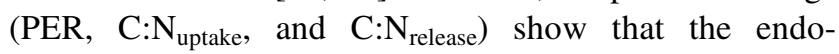
symbionts are actively absorbing and releasing $\mathrm{N}$, indicating that this process is a vital pump maintaining the coral-algal symbiotic metabolism. Therefore, the endosymbionts might not be under $\mathrm{N}$ limitation. At the scale of a reef, primary producers actively consume DIC to synthesize organic $\mathrm{C}$; however, due to the very limited availability of inorganic $\mathrm{N}$ in seawater, the $\mathrm{C}: \mathrm{N}$ stoichiometry in coral reefs appears imbalanced [17]. The results of the present study show that the C:N stoichiometry may be actually well balanced with the $\mathrm{N}$ that is stored and circulated in many symbiotic organisms in coral reefs.

The $\mathrm{N}$ turnover rate of the whole tissue (endosymbionts + animal host) was calculated as $0.27 \% \mathrm{~d}^{-1}$ (Fig. 3), which was 10 times slower than the $\mathrm{C}$ turnover rate $\left(2.7 \% \mathrm{~d}^{-1}\right.$; Fig. 2b). The slow $\mathrm{N}$ turnover rate means that it takes 370 days (residence time $=1 / 0.27 \% \mathrm{~d}^{-1}$ ) for $63 \%$ of $\mathrm{N}$ to be replaced with new $\mathrm{N}$ from the ambient seawater, including uptake from both autotrophic and heterotrophic sources. This conservative behavior of $\mathrm{N}$ can be achieved by the $\mathrm{N}$ cycles through the endosymbionts, and these metabolic characteristics may be an evolutionary adaptation of symbiotic corals to oligotrophic reef environments that allows them to sustain $\mathrm{N}$ for a long time. If all endosymbionts were lost from the animal host (e.g., coral bleaching), $\mathrm{N}$ might be lost from the host tissue, as seen in studies on aposymbiotic corals [56], and the resulting $\mathrm{N}$ residence time in the host tissue (56 days $=1.8 \% \mathrm{~d}^{-1}$; Fig. 3) would be much shorter than that in the symbiotic condition (370 days). Nitrogen retention within algainvertebrate symbioses were also suggested for some other coral species [5, 30], the giant clam Tridacna gigas [57], the planktonic foraminiferan Orbulina universa [41], and the green hydra [58]. The present study quantified the specific efficiency of algal symbiosis and how it influenced the ability of the animal host to enhance its $\mathrm{N}$ conservation. Similar calculations for other symbiotic organisms would also clarify their competitive advantage in terms of $\mathrm{N}$ retention. A long turnover time of $\mathrm{N}$ within symbiosis also indicates that the internal $\mathrm{N}$ would not be immediately replaced with external $\mathrm{N}$. The $\delta^{15} \mathrm{~N}$ of the coral tissue or the organic matrix in the carbonate skeleton has been used to assess the $\mathrm{N}$ source [33-35], but the present study shows that a long time lag may be required for the $\delta^{15} \mathrm{~N}$ values in corals to reflect the $\delta^{15} \mathrm{~N}$ values of the original source.

Coral endosymbionts have been thought to be important for symbiosis in terms of autotrophic $\mathrm{C}$ production $[5,16]$, and the symbiotic relationship is described as a "controlled parasitism," where the coral animal host acts as a "farmer" that optimizes the receipt of autotrophic C-rich organic matter from the endosymbionts [59]. The present study showed that the coral animal host derived $99 \%$ of its total $\mathrm{N}$ acquisition from the endosymbionts (Fig. 3), resulting in the new hypothesis that the animal host farms the endosymbionts to exploit both $\mathrm{C}$ and $\mathrm{N}$ very efficiently through the two different pathways (i.e., extracellular release and algal digestion). Simultaneously, the coral endosymbionts are acting as an essential absorber of the $\mathrm{N}$ wasted by the animal host [15], thereby preventing $\mathrm{N}$ from being lost from the symbiosis, as discussed above. Global seawater warming tends to damage the metabolism of endosymbionts or expel them from the animal host [23, 38, 39], and this causes a decline in the active and conservative microscale $\mathrm{N}$ cycles that are hidden in coral symbiosis and may even trigger a considerable loss of $\mathrm{N}$ reservoirs from the ecosystem. Though the flows of $\mathrm{C}$ and $\mathrm{N}$ through corals should be affected by the coral species [13, 15], the endosymbiont clades [31], and the environmental conditions, such as light intensity [16, 53], the present study showed the first comprehensive model of $\mathrm{C}$ and $\mathrm{N}$ stoichiometry in coral symbiosis. The application of similar isotope labeling and modeling techniques to other symbiotic organisms would further develop our understanding of symbiotic stoichiometry and biogeochemical cycles in the ecosystem.

Acknowledgements We are grateful to H Kinjyo (University of the Ryukyus) for technical assistance in the experiment, T Oono (Taiyo Nippon Sanso Corporation) for stable isotope analyses, J Yamamura (The Global Environmental Forum) for nutrient analyses, and two anonymous reviewers for giving many valuable comments to improve this article. This study was supported by the Japan Society for the Promotion of Science (JSPS) KAKENHI (Grant Numbers 24-3911, 26840149, and 15H02813) and the Universiti Brunei Darussalam CRG Grant (UBD/OAVCRI/CRGWG(013)/170601).

\section{Compliance with ethical standards}

Conflict of interest The authors declare that they have no conflict of interest.

\section{References}

1. Venn AA, Loram JE, Douglas AE. Photosynthetic symbioses in animals. J Exp Bot. 2008;59:1069-80.

2. Yellowlees D, Rees TAV, Leggat W. Metabolic interactions between algal symbionts and invertebrate hosts. Plant Cell Env. 2008;31:679-94. 
3. Engebretson HP, Muller-Parker G. Translocation of photosynthetic carbon from two algal symbionts to the sea anemone Anthopleura elegantissima. Biol Bull. 1999;197:72-81.

4. Hill MS. Production possibility frontiers in phototroph:heterotroph symbioses: trade-offs in allocating fixed carbon pools and the challenges these alternatives present for understanding the acquisition of intracellular habitats. Front Microbiol. 2014;5:357.

5. Tanaka Y, Miyajima T, Koike I, Hayashibara T, Ogawa H. Translocation and conservation of organic nitrogen within the coral-zooxanthella symbiotic system of Acropora pulchra, as demonstrated by dual isotope-labeling techniques. J Exp Mar Biol Ecol. 2006;336:110-9.

6. Weisz JB, Massaro AJ, Ramsby BD, Hill MS. Zooxanthellar symbionts shape host sponge trophic status through translocation of carbon. Biol Bull. 2010;219:189-97.

7. Falkowski P, Dubinsky Z, Muscatine L, Porter JW. Light and the bioenergetics of a symbiotic coral. BioScience. 1984;34:705-9.

8. Tremblay P, Grover R, Maguer J-F, Legendre L, Ferrier-Pagès C. Autotrophic carbon budget in coral tissue: a new ${ }^{13} \mathrm{C}$-based model of photosynthates translocation. J Exp Biol. 2012;215:1384-93.

9. Fabricius KE. Effects of terrestrial runoff on the ecology of corals and coral reefs: review and synthesis. Mar Poll Bull. 2005;50:125-46.

10. Hoegh-Guldberg O, Mumby PJ, Hooten AJ, Steneck RS, Greenfield P, Gomez E, et al. Coral reefs under rapid climate change and ocean acidification. Science. 2007;318:1737-42.

11. Godinot $\mathrm{C}$, Ferrier-Pagès $\mathrm{C}$, Montagna $\mathrm{P}$, Grover R. Tissue and skeletal changes in scleractinian coral Stylophora pistillata Esper 1797 under phosphate enrichment. J Exp Mar Biol Ecol. 2011;409:200-7.

12. Sawall Y, Teichberg MC, Seemann J, Litaay M, Jompa J, Richter C. Nutritional status and metabolism of the coral Stylophora subseriata along a eutrophication gradient in Spermonde Archipelago (Indonesia). Coral Reefs. 2011;30:841-53.

13. Tanaka Y, Grottoli AG, Matsui Y, Suzuki A, Sakai K. Effects of nitrate and phosphate availability on the tissues and carbonate skeleton of scleractinian corals. Mar Ecol Prog Ser. 2017;570:101-12.

14. Rahav O, Dubinsky Z, Achituv Y, Falkowski PG. Ammonium metabolism in the zooxanthellate coral, Stylophora pistillata. Proc R Soc Lond B. 1989;236:325-37.

15. Tanaka Y, Grottoli AG, Matsui Y, Suzuki A, Sakai K. Partitioning of nitrogen sources to algal endosymbionts of corals with longterm ${ }^{15} \mathrm{~N}$-labelling and a mixing model. Ecol Model. 2015;30910:163-9.

16. Tremblay P, Grover R, Maguer JF, Hoogenboom M, FerrierPagès C. Carbon translocation from symbiont to host depends on irradiance and food availability in the tropical coral Stylophora pistillata. Coral Reefs. 2014;33:1-13.

17. Atkinson MJ. Biogeochemistry of nutrients. In: Dubinsky Z, Stambler N, editors. Coral reefs: an ecosystem in transition. The Netherlands: Springer; 2011. p. 199-206. .

18. Miyajima T, Hata H, Umezawa Y, Kayanne H, Koike I. Distribution and partitioning of nitrogen and phosphorus in a fringing reef lagoon of Ishigaki Island, northwestern Pacific. Mar Ecol Prog Ser. 2007;341:45-57.

19. Tanaka Y, Ogawa H, Miyajima T. Production and bacterial decomposition of dissolved organic matter in a fringing coral reef. J Oceanogr. 2011a;67:427-37.

20. Tanaka Y, Miyajima T, Watanabe A, Nadaoka K, Yamamoto T, Ogawa H. Distribution of dissolved organic carbon and nitrogen in a coral reef. Coral Reefs. 2011b;30:533-41.

21. Wyatt ASJ, Falter JL, Lowe RJ, Humphries S, Waite AM. Oceanographic forcing of nutrient uptake and release over a fringing coral reef. Limnol Oceanogr. 2012;57:401-19.
22. Kopp C, Pernice M, Domart-Coulon I, Djediat C, Spangeberg JE, Alexander DTL, et al. Highly dynamic cellular-level response of symbiotic coral to a sudden increase in environmental nitrogen. mBio. 2013;4:e00052-13.

23. Grottoli AG, Warner ME, Levas SJ, Aschaffenburg MD, Schoepf $\mathrm{V}$, McGinley $\mathrm{M}$, et al. The cumulative impact of annual coral bleaching can turn some coral species winners into losers. Glob Change Biol. 2014;20:3823-33.

24. Carpenter KE, Abrar M, Aeby G, Aronson RB, Banks S, Bruckner A, et al. One-third of reef-building corals face elevated extinction risk from climate change and local impacts. Science. 2008;321:560-3.

25. Albright R, Caldeira L, Hosfelt J, Kwiatkowski L, Maclaren JK, Mason BM, et al. Reversal of ocean acidification enhances net coral reef calcification. Nature. 2016;531:362-5.

26. Wild C, Huettel M, Klueter A, Kremb SG, Rasheed MYM, Jørgensen BB. Coral mucus functions as an energy carrier and particle trap in the reef ecosystem. Nature. 2004;428:66-70.

27. de Goeij JM, van Oevelen D, Vermeij MJA, Osinga R, Middlburg JJ, de Goeij AFPM, et al. Surviving in a marine desert: the sponge loop retains resources within coral reefs. Science. 2013;342:108-10.

28. Galván K, Fleeger JW, Peterson B, Drake D, Deegan LA, Johnson DS. Natural abundance stable isotopes and dual isotope tracer addition help to resolve resources supporting a saltmarsh food web. J Exp Mar Biol Ecol. 2011;410:1-11.

29. Van den Meersche K, Soetaert K, Middlburg JJ. Plankton dynamics in an estuarine plume: a mesocosm ${ }^{13} \mathrm{C}$ and ${ }^{15} \mathrm{~N}$ tracer study. Mar Ecol Prog Ser. 2011;429:29-43.

30. Kopp C, Domart-Coulon I, Escrig S, Humbel BM, Hignette M, Meibom A. Subcellular investigation of photosynthesis-driven carbon assimilation in the symbiotic reef coral Pocillopora damicornis. mBio. 2015;6:e02299-14.

31. Baker DM, Andras JP, Jordán-Garza AG, Fogel ML. Nitrate competition in a coral symbiosis varies with temperature among Symbiodinium clades. ISME J. 2013;7:1248-51.

32. Seemann J. The use of ${ }^{13} \mathrm{C}$ and ${ }^{15} \mathrm{~N}$ isotope labeling techniques to assess heterotrophy of corals. J Exp Mar Biol Ecol. 2013;442:88-95.

33. Heikoop JM, Risk MJ, Lazier AV, Edinger EN, Jompa J, Limmon $\mathrm{GV}$, et al. Nitrogen-15 signals of anthropogenic nutrient loading in reef corals. Mar Poll Bull. 2000;40:628-36.

34. Wang XT, Sigman DM, Cohen AL, Sinclair DJ, Sherrell RM, Weigand MA, et al. Isotopic composition of skeleton-bound organic nitrogen in reef-building symbiotic corals: a new method and proxy evaluation at Bermuda. Geochim Cosmochim Acta. 2015;148:179-90.

35. Yamazaki A, Watanabe T, Tsunogai U, Hasegawa H, Yamano H. The coral $\delta^{15} \mathrm{~N}$ record of terrestrial nitrate loading varies with river catchment land use. Coral Reefs. 2015;34:353-62.

36. Marsh JA. Primary productivity of reef-building calcareous red algae. Ecology. 1970;51:255-63.

37. Gustafsson MSM, Baird ME, Ralph PJ. The interchangeability of autotrophic and heterotrophic nitrogen sources in scleractinian coral symbiotic relationships: a numerical study. Ecol Model. 2013;250:183-94.

38. Hoegh-Guldberg O, Smith GJ. The effect of sudden changes in temperature, light and salinity on the population density and export of zooxanthellae from the reef corals Stylophora pistillata Esper and Seriatopora hystrix Dana. J Exp Mar Biol Ecol. 1989;129:279-303.

39. Tanaka Y, Inoue M, Nakamura T, Suzuki A, Sakai K. Loss of zooxanthellae in a coral under high seawater temperature and nutrient enrichment. J Exp Mar Biol Ecol. 2014;457:220-5. 
40. Titlyanov EA, Titlyanova TV, Leletkin VA, Tsukahara J, van Woesik R, Yamazato K. Degradation of zooxanthellae and regulation of their density in hermatypic corals. Mar Ecol Prog Ser. 1996;139:167-78.

41. Uhle ME, Macko SA, Spero HJ, Lea DW, Ruddiman WF, Engel $\mathrm{MH}$. The fate of nitrogen in the Orbulina universa foraminifera-symbiont system determined by nitrogen isotope analyses of shell-bound organic matter. Limnol Oceanogr. 1999;44:1968-77.

42. Bronk DA. Rates of $\mathrm{NH}_{4}{ }^{+}$uptake, intracellular transformation and dissolved organic nitrogen release in two clones of marine Synechococcus spp. J Plankton Res. 1999;21:1337-53.

43. Varela MM, Bode A, Fernández, Gónzalez N, Kitidis V, Varela $\mathrm{M}$, et al. Nitrogen uptake and dissolved organic nitrogen release in planktonic communities characterised by phytoplankton size-structure in the Central Atlantic Ocean. Deep-Sea Res I. 2005;52:1637-61.

44. Gates RD, Hoegh-Guldberg O, McFall-Ngai MJ, Bil KY, Muscatine L. Free amino acids exhibit anthozoan "host factor" activity: They induce the release of photosynthates from symbiotic dinoflagellates in vitro. Proc Natl Acad Sci USA. 1995;92:7430-4.

45. Sutton DC, Hoegh-Guldberg O. Host-zooxanthella interactions in four temperate marine invertebrate symbioses: assessment of effect of host extracts on symbionts. Biol Bull. 1990;178:175-86.

46. Davy SK, Allemand D, Weis VM. Cell biology of cnidariandinoflagellate symbiosis. Microbiol Mol Biol Rev. 2012;76:229-261.

47. Ishikura M, Adachi K, Maruyama T. Zooxanthellae release glucose in the tissue of a giant clam. Tridacna crocea Mar Biol. 1999;133:665-73.

48. Gallop A. Evidence for the presence of a 'factor' in Elysia viridis which stimulates photosynthate release from its symbiotic chloroplasts. New Phytol. 1974;73:1111-7.

49. Kato Y, Imamura N. Metabolic control between the symbiotic Chlorella and the host Paramecium. In: Fujishima M, editor. Endosymbionts in Paramecium. Berlin Heidelberg: SpringerVerlag; 2009. p. 57-82.

50. Furla P, Galgani I, Durand I, Allemand D. Sources and mechanisms of inorganic carbon transport for coral calcification and photosynthesis. J Exp Biol. 2000;203:3445-57.
51. Biddanda B, Benner R. Carbon, nitrogen, and carbohydrate fluxes during the production of particulate and dissolved organic matter by marine phytoplankton. Limnol Oceanogr. 1997;42:506-18.

52. Brzezinski MA, Dickson M-L, Nelson DM, Sambrotto R. Ratios of Si, C and N uptake by microplankton in the Southern Ocean. Deep-Sea Res II. 2003;50:619-33.

53. Muscatine L, Falkowski PG, Porter JW, Dubinsky Z. Fate of photosynthetic fixed carbon in light- and shade-adapted colonies of the symbiotic coral Stylophora pistillata. Proc R Soc Lond B. 1984;222:181-202.

54. Wetz MS, Wheeler PA. Release of dissolved organic matter by coastal diatoms. Limnol Oceanogr. 2007;52:798-807.

55. Ezzat L, Maguer J-F, Grover R, Ferrier-Pagès C. New insights into carbon acquisition and exchanges within the coral-dinoflagellate symbiosis under $\mathrm{NH}_{4}{ }^{+}$and $\mathrm{NO}_{3}{ }^{-}$supply. Proc R Soc B. 2015;282:20150610.

56. Szmant AM, Ferrer LM, FitzGerald LM. Nitrogen excretion and $\mathrm{O}: \mathrm{N}$ ratios in reef corals: evidence for conservation of nitrogen. Mar Biol. 1990;104:119-27.

57. Hawkins AJS, Klump DW. Nutrition of the giant clam Tridacna gigas (L.). II. Relative contributions of filter-feeding and the ammonium-nitrogen acquired and recycled by symbiotic alga towards total nitrogen requirements for tissue growth and metabolism. J Exp Mar Biol Ecol. 1995;190: 263-90.

58. Rees TAC, Ellard FM. Nitrogen conservation and the green hydra symbiosis. Proc R Soc Lond B. 1989;236:203-12.

59. Wooldridge SA. Is the coral-algae symbiosis really 'mutually beneficial' for the partners? Bioessays. 2010;32:615-25.

60. Tanaka Y, Miyajima T, Koike I, Hayashibara T, Ogawa H. Production of dissolved and particulate organic matter by the reefbuilding corals Porites cylindrica and Acropora pulchra. Bull Mar Sci. 2008;82:237-45.

61. Yamazaki A, Watanabe T, Tsunogai U. Nitrogen isotopes of organic nitrogen in reef coral skeletons as a proxy of tropical nutrient dynamics. Geophys Res Lett. 2011;38:L19605.

62. Yamamuro M, Kayanne H, Minagawa M. Carbon and nitrogen stable isotopes of primary producers in coral reef ecosystems. Limnol Oceanogr. 1995;40:617-21. 